\title{
EFFECT OF GROWTH REGULATORS ON AFRICAN PEAR (DACRYODES EDULIS (G. DON) H.J. LAM) FLOWERING, FRUITING AND FRUIT SET
}

\author{
Njoku, T.C.* and Okorie, H. A. \\ Department of Crop Science and Biotechnology, Imo State University, P. M. B 2000, Owerri, \\ Imo State, Nigeria. \\ E-mail: tcnjoku2011@yahoo.com; hilaryokorie@ymail.com
}

\begin{abstract}
Many tropical fruit trees flower profusely. Majority produce many fruits at the onset. Most of these fruits if not all, may be aborted. African pear is a typical example. In this research, four fruit abortion-prevention treatments were evaluated namely: Distilled water, Urea, Giberellin and Coconut water. Floral and pomological parameters were compared and averaged over a period of three consecutive years. At fruit maturity, number of fruits/inflorescence/branches was counted and compared to test the effects of the various treatments on fruit retention and enhancing its pomological characteristics. The design was Randomized complete block design. Regression and correlation in Statgraphic 16.0 software package were used to compare the effects of the various treatments on flowering, fruiting and fruit retention. Application of growth regulators significantly enhanced flowering, fruiting and fruit set. The best fruit retention of $76.56 \%$ was obtained by Coconut water which was however, not significantly $(P=0.05)$ different from $72.75 \%$ fruit set obtained by Giberellin. Distilled water gave the lowest fruit-set of $21.41 \%$ which was however significantly $(P=0.05)$ different from $66.48 \%$ obtained by Urea. There was no significant difference $(P=0.05)$ in some of the pomological attributes measured. Application of Giberellin and Coconut water significantly $(P=0.05)$ enhanced flowering, fruiting and fruitset in African pear.
\end{abstract}

Key words: Growth regulator, flowering, fruiting, fruit-set

https://dx.doi.org/10.4314/jafs.v19i1.2

\section{INTRODUCTION}

The natural fruit drop in tropical fruit trees has been considered a major cause of low fruit yield in fruit trees like Africa pear (D. edulis). Many of them flower profusely and majority produces many fruits at the onset. Later, most of these fruits if not all, may be aborted posing problems to their owner's. Saleem et al. , (2008) considered poor fruit set in citrus as a problem leading to low income to farmers, in addition to malnourishment and starvation also natural fruits drop in citrus is too high amounting to about $81-91 \%$ at various stages of growth. This is harmful to the

Journal of the Faculty of Agriculture and Veterinary Medicine, Imo State University Owerri website: www ajol.info; Attribution:Non- commercial CC BY-NC 
Journal of Agriculture and Food Sciences

Njoku, T.C. and Okorie, H. A.

Volume 19 Number 1, April 2021 pp 18-30

worlds food supply. There are several causes of fruit drop including nutrients deficiency, competition between developing fruit lets, drought or lack of irrigation, unfavourable climatic condition during fruit developments period (wind and hail storm) incidence of serious diseases like powdery mildew and anthracnose and pests like hopper and mealy bug (Majumder \& Sharma, 1990). In spite of adequate flowering, low fruit yield in mango orchards have been experienced because of low initial fruit-set and subsequently higher fruit abscission (Wahdan et al., 2011).

Abscission of fruit let is a very complex physiological process, occurring in many cultivars of mango at all stages of development. It is particularly higher during the first 3-4 weeks after pollination and account for over $90 \%$ of loss of set fruit lets (Wahdan \& Melouk, 2004). Bains et al., (1997) and Wahdan et al., (2011), identified several other factors affecting fruit let abscission and some of the reasons include lack of pollination, failure of fertilization, ovule abortion and embryo degeneration, hormone content, climatic factors (day length, temperature and wind) inadequate soil moisture and low photosynthate level.

African pear (Dacryodes edulis) is a tropical fruit tree species (TFTS) which is mainly available between the month of April to September when farmers have planted their crops and there is food scarcity. It is eaten during this period with maize (Zea mays L) to overcome hunger (Okorie, 2001). The fruit enhances nursing mothers' breast milk, rich in high quality oil and also a raw material for manufacturing soap, Margarine, paints, candles etc also in pharmacology. It is a multi-purpose tree with important socio- economic and agronomic potentials in the region (Okorie, 2001; Opeke, 2012).

Naturally occurring hormones play a major role in fruit growth and fruit set (RAM, 1992; Mibus et al., 2014). The ability of gibberellins, cytokines, coconut water, Urea and auxins etc to promote flowering, fruiting and fruit set under conditions that would not normally permit flowering, fruiting \& fruit set contributed to the realization that these compounds may function as exogenous growth regulators (Effie \& Peter, 2009).

Deficiency of gibberellins, auxins and cytokinins followed with a high level of growth inhibitors causes' fruit drop. Increase concentrations of abscisic acid and ethylene in the panicle results to formation of abscission layer at the site of fruit attachment which finally drops down (Singh, 2012). Muchjajib, et al., (2014), discovered that an increase in auxins or gibberellins levels Journal of the Faculty of Agriculture and Veterinary Medicine, Imo State University Owerri website: www ajol.info; Attribution:Non- commercial CC BY-NC 
Journal of Agriculture and Food Sciences

Njoku, T.C. and Okorie, H. A.

Volume 19 Number 1, April 2021 pp 18-30

corresponds with a period of rapid growth while a higher level of inhibitors corresponds with high rate of fruit-drop. The auxins have direct effect on abscission which cause a delay of abscission and may result eventually in an increase fruit set in citrus (Basharat, et al., 2007). Application of NAA and GA (Muchjajib et al., 2014) and caffeine (Kretzschmar et al., 2014) have been found effective in reducing the fruit drop and enhancing the fruit set. Wahdan et al; (2011) found that the highest fruit retention and yield / tree were recorded on mango cv (Amrapali) by spraying urea with 3\% at pea stage. Gomez Cadens et al., (2000) reported that exogenous application of gibberellin had no effect on abscission in citrus. Application of different growth regulators (GA, 2, 4-D and NAA) alone and in combination on pear orange had no influence on the development of the fruit such as length diameter and fresh fruit mass (Almeida et al., 2004). The main objective of this study was to investigate the effect of growth regulators on African pears (D. edulis (G. Don) flowering fruiting and fruit set.

\section{MATERIAL AND METHOD}

\section{Experimental Location and Fruit Conditions}

The experiment was conducted under rain fed conditions using 17yrs old African pear (Dacryodes edulis) tree growing at experimental African pear orchard of Imo State University farm Owerri, Imo State (Latitude $05^{0} 26^{\prime} \mathrm{N}$, longitude $07^{\circ} 02^{\prime} \mathrm{E}$ an altitude $91 \mathrm{~m}$ above sea level). The fruit source were different African pear (AP) fruit types collected from different parts of South - East and South -South Nigeria on earlier characterization study (Okorie, 2001). The trees were spaced $4.5 \mathrm{~m} \times 4.5 \mathrm{~m}$ in a triangular system growing under similar condition and under the same cultural practice during the period of study.

This part of the humid tropics in south eastern Nigeria is characterized by a warm wet season in mid-march to October, and a hot dry season in November to mid-march. The annual precipitation ranges from 1,810 -2,260 $\mathrm{mm}$ and most of it falls during the wet season. There is a short duration drought of about 10 days in August. During the wet season, much of the daytime has a near saturation point relative humidity with maximum and minimum temperatures of 30 and $21^{\circ} \mathrm{C}$ respectively.

Journal of the Faculty of Agriculture and Veterinary Medicine, Imo State University Owerri website: www ajol.info; Attribution:Non- commercial CC BY-NC 
Journal of Agriculture and Food Sciences

Volume 19 Number 1, April 2021 pp 18-30

Njoku, T.C. and Okorie, H. A.

Experimental procedure and field planting

Seventeen (17) year old African pear fruit types were used. Sixteen trees were selected; four growth regulators were sprayed at a concentration of $\mathrm{T}_{1}$-Distilled water, $\mathrm{T}_{2}$-Urea $4 \% ; \mathrm{T}_{3}$ gibberellin $4 \%$ and $\mathrm{t}_{4}$ - coconut water $50 \%$ three weeks before flowering and 2 weeks after flowering. this was repeated for a period of three years. The experiment was set in a randomized complete block design with four replications. The trees form the block, and each block consists of four mature African pear trees. Before spraying, each tree was divided into four compartments of equal size. A branch from each compartment serves as a treatment unit and was tagged for data collection.

\section{Data collection and analytical techniques}

The data on important crop and yield attributes were collected using the same procedure in each block; ten (10) fruits were collected from each treatment unit. Fruits were weighed immediately after harvest using an electronic weighing balance. Pomological attributes such as fruit longitudinal circumference, (FLC) fruit length (FL), fruit Diameter (FD), pulp thickness (PT) etc were checked using a measuring tape. The initial number of fruits per panicle was counted two to three weeks after flowering before second hormone application to determine the initial number of fruits per panicle. Also, the number of trees that flowered was counted to determine the effect of hormone on flowering per tree. Number of fruits per panicle was counted every two weeks (bi- weekly) to check the rate of fruit drop. After recording the initial number of fruits, at maturity the number of fruits per panicle was recorded. The percentage of retained fruits at harvest time was calculated. The experiment was carried out for three consecutive years.

Data analyses were carried out using the multiple analysis of variance (ANOVA) techniques in Statgraphic model version16.0. Means were separated using Fishers Least Significant Difference (LSD at 5\%) procedure as in statgraphic package version 16.0 model, and Duncan's New Multiple Range Test (DNMRT). The mean and coefficients of variation for flowering, fruiting \& fruit set evaluated were calculated for the three years.

Journal of the Faculty of Agriculture and Veterinary Medicine, Imo State University Owerri website: www ajol.info; Attribution:Non- commercial CC BY-NC 
Journal of Agriculture and Food Sciences

Volume 19 Number 1, April 2021 pp 18-30

Njoku, T.C. and Okorie, H. A. RESULTS

\section{Effect of growth regulator on flowering}

Foliar application of treatment significantly increased the number of trees that flowered compared with control, (Table 1). The highest values (13.75 and 13.50) were obtained from Gibberellin 4\% and coconut water 50\% in 2014 while the control gave the lowest values of 9.75 . All concentrations of coconut water 50\% had no significant effect with control in 2015 (10.75 and 9.75) but significantly different from urea and Gibberellin (12.75 and 13.75). Flowering was significantly increased by using urea, Gibberellins and coconut water $(13.75,13.50$ and 13.75) in 2016 compared with control (9.75). In all the years the mean number of trees that flowered remained the same $(9.75)$.

\section{Effect of growth Regulators on fruiting}

Data in Table 2 indicates that growth regulator had no significant effect on mean initial number of fruits in 2014 also in 2016. GA was significantly $(\mathrm{P}=0.05)$ different from all others. Meanwhile all were significantly $(\mathrm{P}=0.05)$ different $(438.25,609.25,813.25$ and 565.25$)$ in 2015. Treatment 3 had the highest mean initial number of fruit (813.25), which was closely followed by Treatment 2 (609.25) with treatment 1 having the lowest mean initial number of fruits.

\section{Effect of growth Regulators on fruit set}

The mean fruit set were generally significant across the three years. In 2014, the mean fruit set were statistically similar among the treatments but significantly $(\mathrm{P}=0.05)$ different from the control (Table 3). Also, the mean fruit set were significantly $(\mathrm{P}=0.05)$ different in the $2^{\text {nd }}$ year among the treatments. The highest mean fruit set were 632.50 obtained from Gibberellin $\left(\mathrm{T}_{3}\right)$. The lowest mean fruit set was from control. In 2016 treatment 2(urea) were statistically similar with $\mathrm{T}_{4}$ (coconut water). These were statistically different from $\mathrm{T}_{3}$ (Gibberellin). All these were significantly $(\mathrm{P}=0.05)$ different from $\mathrm{T}_{1}$ (control). $\mathrm{T}_{3}$ recorded the highest mean fruit set of 559.00 with CV value of 16.46 .

\section{Effect of Growth Regulators on percentage (\%) fruit drop}

The Multiple analysis of variance with respect to mean fruit set and percentage (\%) fruit set combined, showed that fruit set was lowest with treatment 1 and highest with treatment 3 (Table Journal of the Faculty of Agriculture and Veterinary Medicine, Imo State University Owerri website: www ajol.info; Attribution:Non- commercial CC BY-NC 
Journal of Agriculture and Food Sciences

Njoku, T.C. and Okorie, H. A.

Volume 19 Number 1, April 2021 pp 18-30

5). The mean fruit set ranges from 112.17 to 561.58. Percentage fruit set showed that treatment 4 (coconut water) with a mean fruit set of 456.17 and $76.56 \%$ had the highest fruit set. This was closely followed by Gibberellin with a mean fruit set of 561.58 and percentage fruit set of 72.75\%. Table 6 reveals that growth regulators have no significant $(\mathrm{P}=0.05)$ effect on the pomological characteristics measured.

\section{DISCUSSION}

The application of growth regulators at different concentration on Africa pear (AP) tree for three years gave mean flowering ranging from 9.75 to 13.67 . The mean flowering obtained from the three years irrespective of treatment ranges from 11.75 to 12.69 . In 2014, all treatment showed a statistically significant difference. Multiple range test shows that mean treatment 1 (control) is significantly $(\mathrm{P}=0.05)$ different from all other treatments. In 2015, treatment 1 and 4 were statistically similar whereas treatment 2 and 3 were statistically similar but significantly $(\mathrm{P}=$ 0.05) different from treatment 1 and 4. Treatments had a significant effect on flowering in 2016. All the treatments were statistically the same but significantly $(\mathrm{P}=0.05)$ different from treatment 1 (control). Irrespective of the year, gibberellins $\left(\mathrm{T}_{3}\right)$ gave the highest mean flowering of 13.67 where as control $\left(\mathrm{T}_{1}\right)$ gave the lowest mean flowering of 9.75 . The initial mean number of fruits evaluated irrespective of treatment ranges from 606.50 to 657.00 . The mean numbers of fruit were statistically similar in 2014. In 2015 and 2016 means were significantly $(P=0.05)$ different. Mean fruiting were significantly $(\mathrm{P}=0.05)$ different among all treatments in 2015 which ranges from 438.25-813.25 but in 2016 Gibberellin were significantly different among all others with the highest fruit mean of 770.00 among all the treatment evaluated, Gibberellin has the highest mean number of fruits for the three years $(732.50 ; 813.25$ and 770.00$)$ respectively. This was closely followed by urea $(655.00 ; 609.25$ and 630.00). The least was control (611.50, 438. 25 and 522. 000 respectively. Unlike initial mean number of fruits in 2014, means fruit set in 2014 were significantly $(P=0.05)$ different. $T_{1}$ was significantly different from all others. The highest mean fruit set was recorded by $\mathrm{T}_{3}$ (493.25). In 2015, mean fruit set were significantly (P $=0.05)$ different across all treatments despite the fact that the mean initial number of fruits was the same. This showed that treatment had effect on the mean fruit set for the three years. Concerning fruit retention percentage, data in Table 4 illustrated that all treatments in both years

Journal of the Faculty of Agriculture and Veterinary Medicine, Imo State University Owerri website: www ajol.info; Attribution:Non- commercial CC BY-NC 
Journal of Agriculture and Food Sciences

Njoku, T.C. and Okorie, H. A.

Volume 19 Number 1, April 2021 pp 18-30

obtained from trees showed significant $(\mathrm{P}=0.05)$ difference across the treatment. The highest percentage fruit retention was recorded by $\mathrm{T}_{4}$ (coconut water) $(76.56 \%)$ this was followed by $\mathrm{T}_{3}$ (Gibberellin) (72.75\%) and the lowest was recorded by $\mathrm{T}_{1}$ (control) $(21.41 \%)$.

The mean fruit number and percentage fruit set per tree showed high variation values ranging from 21.41-76.56\%. The control (Distilled water) treatment gave the least mean number of fruits at Maturity (21. 41\%) 112.17. The initial mean fruit number per tree were 771.92; 631. 42; 595.83 and 523. 92 respectively. The corresponding percentage fruit set values were $72.75 \%, 66$. $48 \%, 76.56 \%$ and $21.41 \%$ respectively. Poor fruit set in African pear is considered an important limiting factor for yield. Maximum fruit set were dropped before the application of treatment due to low yielding trend of trees, so the plant growth regulators gave its, least response to fruit drop. Wahdan (2011) reported that low fruit yield was experienced in Mango, because of low initial fruit set. Muchjajib et al., (2014) obtained the best fruit retention with NNA and GA. Wahdan et al., (2011) discovered that 3\% urea gave the highest fruit retention in Mango.

\section{CONCLUSION}

In this study, Urea, Gibberellins, \& coconut water proved to be an effective growth regulator in increasing fruit set in African pear by prohibiting the adverse effect of growth inhibitors. The result also confirmed the role of these growth regulators in fruit development and fruit set when applied exogenously. It can be concluded on the basis of this result that coconut water can effectively improve fruit set in African pear when applied two weeks after flowering just like Gibberellins and urea. In the absence of Gibberellins and Urea, coconut water can be used hence it can serve the same purpose.

Journal of the Faculty of Agriculture and Veterinary Medicine, Imo State University Owerri website: www ajol.info; Attribution:Non- commercial CC BY-NC 
Journal of Agriculture and Food Sciences

Volume 19 Number 1, April 2021 pp 18-30

Njoku, T.C. and Okorie, H. A.

REFERENCES

Almeida, I. M. L. de, J.D. Rodrigues and E.O Ono (2004). Application of plant growth regulators at preharvest for fruit development of pera' Oranges. Brazilian Archives of Biology and Technology 47(4):511-520. https://doi.org/10.1590/S1516-89132004000400003

Bains, K.S., Habib, G.E., and Singh, Z. (1999). Abscission of Mango fruit lets. I. In relation to endogenous concentrations of IAA, GA and ABA in pedicels and fruitlets. Fruits, 52: 159165.

Basharat, A.S., U.M. Aman, and F. Muammad (2007). Effect of exogenous growth regulators application on June fruit drop and fruit quality in citrus sinensis CV. Blood red. Pak. Journal of Agric Science, 44(2): 289-294.

Effie, M. G., and H. Peter (2009). Gibberellin as a factor in floral regulatory Networks. Experimental botany J., Broom's Ban Research Centres, 60 (7); 1979-1989. https://doi.org/10.1093/jxb/erp040

Gomez-Candenas, A.J. Mehouachi, F.R. Tadeo, E. Primo-Millo and M. Talon (2000). Hormonal regulation of fruitlet abscission induced by carbohydrate shortage in citrus. Planta 210: 636- 643. https://doi.org/10.1007/s004250050054

Kretzschmar, A.A., S.C. Ubor, L. Rufato, T.A Macedo, G.F Sander, F.N Silvera, R. Voss, J.R. Rodrigues, L. Cayaneo and D. S. Souza (2014). The use of caffeine as a growth regulator in apple tree. Santa Caterina State University Lages, Brazil.

Majunder, P. K. and D. K. Sharma, (1990). In Fruits Tropical and Subtropical. T. K Bose and S.K. Mitra (eds), pp:1-62. Naya Prokash, Calacuta.

Mibus, H., K. Hoff, and M. Serek (2014). New strategies for induction of compact growth in kalanchoe flowering potted plants. Faculty of Natural Sci. institute of Hort. Prod Sys. Univ. of Hannover Germany. https://doi.org/10.1016/j.scienta.2014.01.032

Muchjajib S.I., U. I. Muchjajib, M. Jumee (2014). Effect of GA and NAA application and fruit wrapping on yield and quality of Java apple (Zyzygium samarangens (Blum) Merrill and Perry)

Okorie, H. A. (2001). Futhering the domestication of Africa pear (Dacryodes edulis (G.Don) H.J.Lam). Sharker.Verlag Publisher. 91 pp.

Opeke. L. K., (2012). Tropical Commodity Tree Cop. Spectrum Books Limited, Ibadan. ISBN:978-029-465-1.

Racsko, J. J., M. Nagy, M. Soleia, J. Nyeki and Z. Szabo, (2006). Fruit drop: Specific characteristics and varietal properties of fruit drop. International Journal of Horticultural Science 12(2): 59-67. https://doi.org/10.31421/IJHS/12/2/635

Journal of the Faculty of Agriculture and Veterinary Medicine, Imo State University Owerri website: www ajol.info; Attribution:Non- commercial CC BY-NC 
Journal of Agriculture and Food Sciences

Volume 19 Number 1, April 2021 pp 18-30

Njoku, T.C. and Okorie, H. A.

Ram, S. (1992). Naturally occurring hormones of mango and their role in growth and drop of fruits. Acta Hort., 321: 400-11. https://doi.org/10.17660/ActaHortic.1992.321.43

Saleem, B.A., A.U. Malik, M. A. Pervez and A. S. Khan (2008). Growth regulators application effects vegetative and reproductive behavior of "Blood Red" Sweet Orange. Institute of Horticultural Science. University of Agriculture Faisalabad Pakistan. Pak. J. Bot., 40:211525.

Singh, J. (2012). Basic Horticulture. College of Horticulture and Forestry (MPUA \& T, Udaipur) jhalar 326023 (Raj.) Kalyani Publishers New Delhi- 2115-25.

Wahdan, M.T. and A.E. Melouk (2004). Effect of amcotone on vegetative growth, fruiting, fruit yield and quality of "Succary Abiad" Mango trees. Agri. Res. J. Suez Canal University. 4(2): 69-76.

Wahdan, M.T., S.E. Habib, M.A Bassal, and E.M. Qaoud (2011). Effect of some chemicals on growth, fruiting, yield and fruit quality of "Succary Abiad" Mango cv. American sci. J. Suez Canal University (7I2): 651-658.

Journal of the Faculty of Agriculture and Veterinary Medicine, Imo State University Owerri website: www ajol.info; Attribution:Non- commercial CC BY-NC 
Volume 19 Number 1, April 2021 pp 18-30

\section{APPENDICES}

Table 1: Effects of growth regulators on African Pear (D. edulis G.Don (HJ) Lam) flowering.

\begin{tabular}{llllllll}
\multicolumn{1}{c}{$\begin{array}{c}\text { Growth } \\
\text { Regulators }\end{array}$} & Mean & $\mathbf{2 0 1 4}$ & \multicolumn{2}{c}{$\mathbf{2 0 1 5}$} & \multicolumn{2}{c}{$\mathbf{2 0 1 6}$} & Grand Mean \\
Control & & $(\%)$ & Mean & CV & Mean & CV & \\
Urea & $9.75^{\mathrm{a}}$ & 9.82 & $9.75^{\mathrm{a}}$ & 9.82 & $9.75^{\mathrm{a}}$ & 16.66 & 9.75 \\
Gibberellin & $12.00^{\mathrm{b}}$ & 6.80 & $12.75^{\mathrm{b}}$ & 7.51 & $13.75^{\mathrm{b}}$ & 6.96 & 12.83 \\
Coconut water & $13.75^{\mathrm{c}}$ & 6.96 & $13.75^{\mathrm{b}}$ & 6.96 & $13.50^{\mathrm{b}}$ & 9.56 & 13.67 \\
Mean & $13.50^{\mathrm{bc}}$ & 9.56 & $10.75^{\mathrm{a}}$ & 8.91 & $13.75^{\mathrm{b}}$ & 6.96 & 12.67 \\
& 12.25 & & 11.75 & & & 12.69 &
\end{tabular}

Table 2: Effects of growth regulators on African Pear (D. edulis G.Don (HJ) Lam) fruiting

\begin{tabular}{llllllll}
\hline $\begin{array}{l}\text { Growth } \\
\text { Regulators }\end{array}$ & \multicolumn{2}{c}{$\mathbf{2 0 1 4}$} & \multicolumn{2}{c}{$\mathbf{2 0 1 5}$} & \multicolumn{2}{c}{$\mathbf{2 0 1 6}$} & \multicolumn{2}{c}{ Grand Mean } \\
& Mean & CV & Mean & CV & Mean & CV \\
& & $(\%)$ & & $(\%)$ & & $(\%)$ & \\
\hline Control & $611.50^{\mathrm{a}}$ & 22.61 & $438.25^{\mathrm{a}}$ & 4.81 & $522.00^{\mathrm{a}}$ & 15 & 523.92 \\
Urea & $655.00^{\mathrm{a}}$ & 13.47 & $609.25^{\mathrm{c}}$ & 3.48 & $630.00^{\mathrm{a}}$ & 7.59 & 631.42 \\
Gibberellin & $732.50^{\mathrm{a}}$ & 33.66 & $813.25^{\mathrm{d}}$ & 2.40 & $770.00^{\mathrm{b}}$ & 16.89 & 771.92 \\
Coconut water & $629.00^{\mathrm{a}}$ & 21.29 & $565.25^{\mathrm{b}}$ & 3.09 & $593.25^{\mathrm{a}}$ & 12.14 & 595.83 \\
Mean & 657.00 & & 606.50 & & 628.81 & & \\
\hline
\end{tabular}


Journal of Agriculture and Food Sciences

Volume 19 Number 1, April 2021 pp 18-30

Njoku, T.C. and Okorie, H. A.

Table 3: Effects of growth regulators on African Pear (D. edulis G.Don (HJ) Lam) fruit set

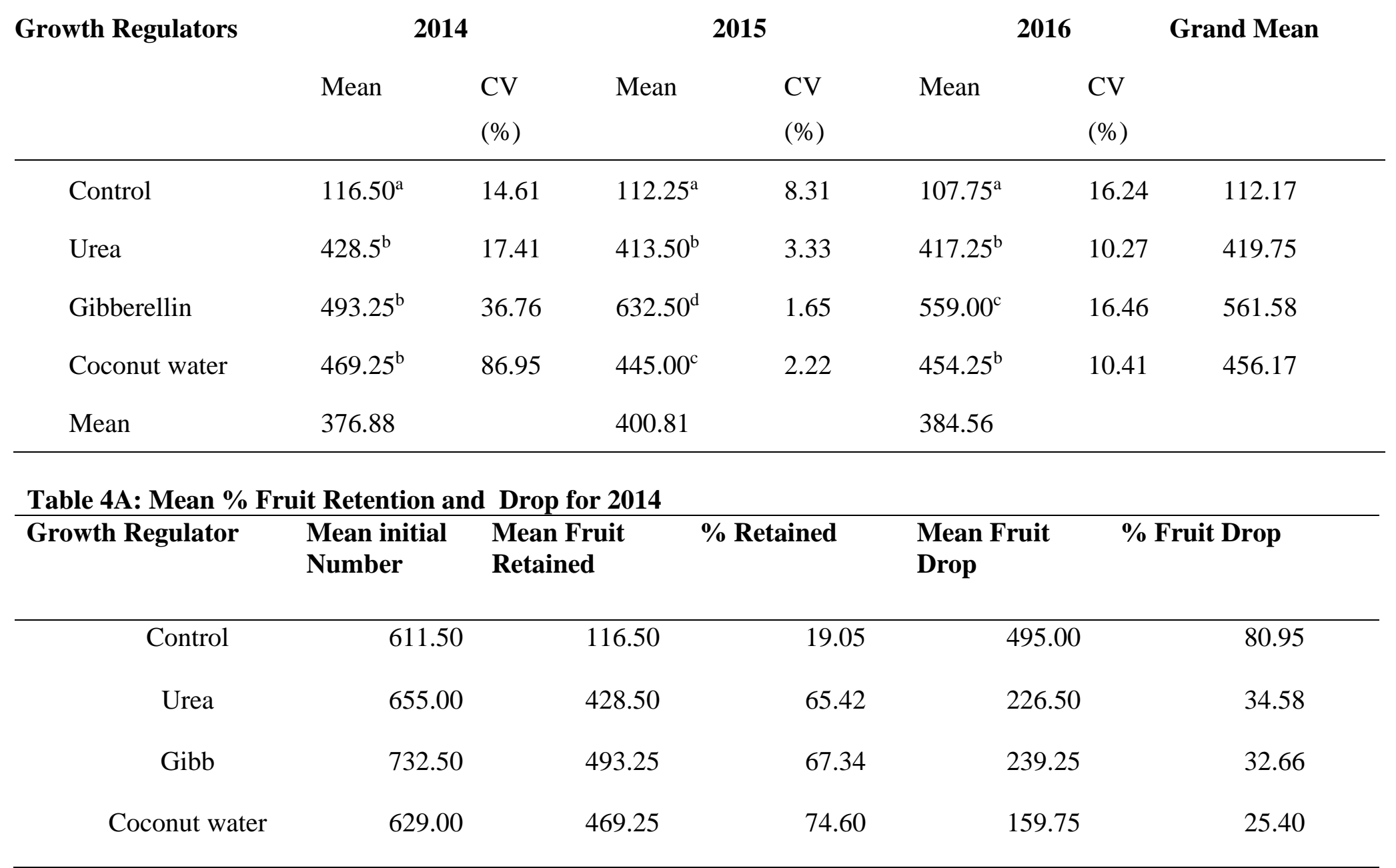


Table 4B: Mean \% Fruit Retention and Drop for 2015

\begin{tabular}{cccccc}
\hline Growth Regulator & $\begin{array}{c}\text { Mean } \\
\text { initial Number }\end{array}$ & Mean Fruit Retained & $\begin{array}{c}\text { \% Retained Mean } \\
\text { Drop }\end{array}$ & Fruit & \% Fruit Drop \\
\hline Control & 438.25 & 112.25 & 25.61 & 326.00 & 74.39 \\
Urea & 609.25 & 413.50 & 67.87 & 195.75 & 32.13 \\
Gibb & 813.25 & 632.50 & 77.77 & 180.75 & 22.23 \\
Coconut water & 565.25 & 445.00 & 78.73 & 120.25 & 21.27 \\
\hline
\end{tabular}

Table 4C: Mean \% Fruit Retention \& Drop for 2016.

\begin{tabular}{|c|c|c|c|c|c|}
\hline Growth Regulator & $\begin{array}{l}\text { Mean initial } \\
\text { Number }\end{array}$ & $\begin{array}{l}\text { Mean Fruit } \\
\text { Retained }\end{array}$ & \% Retained & $\begin{array}{c}\text { Mean Fruit } \\
\text { Dron }\end{array}$ & \% Fruit Drop \\
\hline Control & 522.00 & 107.75 & 20.64 & 414.25 & 79.36 \\
\hline Urea & 630.00 & 417.25 & 66.23 & 212.75 & 33.77 \\
\hline Gibberellin & 770.00 & 559.00 & 72.60 & 211.00 & 27.40 \\
\hline Coconut water & 593.25 & 454.25 & 72.57 & 139.00 & 27.43 \\
\hline
\end{tabular}

Table 5: Effect of Growth Regulators on African Pear (D. edulis (G. Don) H. J. Lam) Percentage (\%) Fruit Drop and Fruit Retention from 2014-2016 combined.

\begin{tabular}{|c|c|c|c|c|c|}
\hline Growth Regulator & $\begin{array}{c}\text { Mean initial } \\
\text { Number }\end{array}$ & $\begin{array}{c}\text { Mean } \\
\text { Retained }\end{array}$ & $\%$ Retained & Mean Fruit Drop & \% Fruit Drop \\
\hline Control & 523.92 & 112.17 & 21.41 & 411.75 & 78.59 \\
\hline Urea & 631.42 & 419.75 & 66.48 & 211.67 & 33.52 \\
\hline Gibberellin & 771.92 & 561.58 & 72.75 & 210.34 & 27.25 \\
\hline Coconut water & 595.83 & 456.17 & 76.56 & 139.66 & 23.44 \\
\hline
\end{tabular}


Journal of Agriculture and Food Sciences

Njoku, T.C. and Okorie, H. A.

Volume 19 Number 1, April 2021 pp 18-30

Table 6: Effect of Growth Regulators on AP (D.edulis (G. Don) HJ Lam) Pomological Characteristics 2014-2016

\begin{tabular}{|c|c|c|c|c|}
\hline \multirow{2}{*}{$\begin{array}{c}\text { Pomological } \\
\text { Characteristic }\end{array}$} & \multicolumn{4}{|c|}{ Growth Regulators } \\
\hline & Control & Urea & Gibberellin & $\begin{array}{l}\text { Coconut } \\
\text { Water }\end{array}$ \\
\hline \multicolumn{5}{|l|}{$\mathrm{FW}(\mathrm{g})$} \\
\hline 2014 & $29.75^{\mathrm{a}}$ & $33.65^{\mathrm{a}}$ & $36.43^{b}$ & $36.43^{\mathrm{b}}$ \\
\hline 2015 & $25.15^{\mathrm{a}}$ & $29.98^{\mathrm{a}}$ & $32.53^{\mathrm{a}}$ & $30.28^{\mathrm{a}}$ \\
\hline 2016 & $31.55^{\mathrm{a}}$ & $32.75^{\mathrm{a}}$ & $32.50^{\mathrm{a}}$ & $36.42^{\mathrm{a}}$ \\
\hline \multicolumn{5}{|l|}{$\mathrm{PW}(\mathrm{g})$} \\
\hline 2014 & $21.31^{\mathrm{a}}$ & $25.20^{\mathrm{a}}$ & $27.40^{\mathrm{b}}$ & $26.78^{\mathrm{b}}$ \\
\hline 2015 & $17.15^{\mathrm{a}}$ & $22.28^{\mathrm{a}}$ & $24.93^{\mathrm{a}}$ & $21.85^{\mathrm{a}}$ \\
\hline 2016 & $22.41^{\mathrm{a}}$ & $24.48^{\mathrm{a}}$ & $26.58^{\mathrm{b}}$ & $26.81^{\mathrm{b}}$ \\
\hline \multicolumn{5}{|l|}{$\mathrm{SW}(\mathrm{g})$} \\
\hline 2014 & $8.43^{\mathrm{a}}$ & $8.35^{\mathrm{a}}$ & $8.85^{\mathrm{a}}$ & $9.55^{\mathrm{a}}$ \\
\hline 2015 & $7.98^{\mathrm{a}}$ & $7.63^{\mathrm{a}}$ & $7.58^{\mathrm{a}}$ & $8.38^{\mathrm{a}}$ \\
\hline 2016 & $9.12^{\mathrm{a}}$ & $8.70^{\mathrm{a}}$ & $8.20^{\mathrm{a}}$ & $9.55^{\mathrm{a}}$ \\
\hline \multicolumn{5}{|l|}{$\mathrm{PT}(\mathrm{mm})$} \\
\hline 2014 & $4.25^{\mathrm{a}}$ & $5.75^{\mathrm{a}}$ & $4.75^{\mathrm{a}}$ & $5.75^{\mathrm{a}}$ \\
\hline 2015 & $4.50^{\mathrm{a}}$ & $4.25^{\mathrm{a}}$ & $5.00^{\mathrm{a}}$ & $4.75^{\mathrm{a}}$ \\
\hline 2016 & $4.50^{\mathrm{a}}$ & $4.50^{\mathrm{a}}$ & $4.50^{\mathrm{a}}$ & $5.70^{\mathrm{b}}$ \\
\hline \multicolumn{5}{|l|}{ NS } \\
\hline 2014 & $11.25^{\mathrm{a}}$ & $12.00^{\mathrm{a}}$ & $12.00^{\mathrm{a}}$ & $14.25^{\mathrm{a}}$ \\
\hline 2015 & $9.50^{\mathrm{a}}$ & $12.25^{\mathrm{a}}$ & $12.00^{\mathrm{a}}$ & $12.50^{\mathrm{a}}$ \\
\hline 2016 & $11.50^{\mathrm{a}}$ & $12.50^{\mathrm{a}}$ & $12.25^{\mathrm{a}}$ & $14.25^{\mathrm{a}}$ \\
\hline \multicolumn{5}{|l|}{$\mathrm{FC}(\mathrm{cm})$} \\
\hline 2014 & $10.20^{\mathrm{a}}$ & $11.15^{\mathrm{a}}$ & $10.73^{\mathrm{a}}$ & $11.55^{\mathrm{a}}$ \\
\hline 2015 & $9.68^{\mathrm{a}}$ & $10.00^{\mathrm{a}}$ & $10.43^{\mathrm{a}}$ & $10.30^{\mathrm{a}}$ \\
\hline 2016 & $10.45^{\mathrm{a}}$ & $10.48^{\mathrm{a}}$ & $10.53^{\mathrm{a}}$ & $11.05^{\mathrm{a}}$ \\
\hline \multicolumn{5}{|l|}{$\mathrm{FD}(\mathrm{cm})$} \\
\hline 2014 & $2.93^{\mathrm{a}}$ & $3.43^{\mathrm{a}}$ & $3.13^{\mathrm{a}}$ & $3.13^{\mathrm{a}}$ \\
\hline 2015 & $2.80^{\mathrm{a}}$ & $3.13^{\mathrm{a}}$ & $3.05^{\mathrm{a}}$ & $3.23^{\mathrm{a}}$ \\
\hline 2016 & $3.25^{\mathrm{a}}$ & $3.10^{\mathrm{a}}$ & $3.20^{\mathrm{a}}$ & $3.13^{\mathrm{a}}$ \\
\hline \multicolumn{5}{|l|}{$\mathrm{FL}(\mathrm{cm})$} \\
\hline 2014 & $4.85^{\mathrm{a}}$ & $5.33^{\mathrm{b}}$ & $5.45^{\mathrm{b}}$ & $5.38^{\mathrm{b}}$ \\
\hline 2015 & $4.70^{\mathrm{a}}$ & $5.25^{\mathrm{a}}$ & $5.03^{\mathrm{a}}$ & $4.98^{\mathrm{a}}$ \\
\hline 2016 & $5.05^{\mathrm{a}}$ & $5.28^{\mathrm{a}}$ & $5.45^{\mathrm{b}}$ & $5.38^{\mathrm{b}}$ \\
\hline
\end{tabular}

Journal of the Faculty of Agriculture and Veterinary Medicine, Imo State University Owerri website: www ajol.info; Attribution:Non- commercial CC BY-NC 